\title{
АНАЛИЗ ФУНКЦИОНИРОВАНИЯ СИСТЕМЫ ОЦЕНКИ ЗНАНИЙ ОБУЧАЮЩИХСЯ
}

\author{
Зарипова Р.С. ${ }^{1}$, Халуева В.В.
}

${ }^{1}$ Казанский государственный энергетический университет,

г. Казань, Российская Федерация

${ }^{2}$ Казанский авиационно-технический колледж

им. П.В. Дементьева, г. Казань, Российская Федерация

Данная исследовательская работа позволила выявить преимущества балльно-рейтинговой системы (БРС) в высшем учебном заведении и доказала, что БРС может быть применима в учебном прочессе как система оценки знаний и одно из средств повышения учебной мотивации, формирования навыка самостоятельной деятельности, развития инициативности, лидерских качеств у студентов.

Ключевые слова: балльно-рейтинговая система; система оценки знаний; промежуточная аттестащия.

\section{ANALYSIS OF THE FUNCTIONING OF THE KNOWLEDGE EVALUATION SYSTEM IN STUDENTS}

\section{Zaripova R.S. ${ }^{1}$, Khalueva $V . V^{2}$}

${ }^{1}$ Kazan State Energy University, Kazan, Russian Federation ${ }^{2}$ Kazan Aviation Technical College, Kazan, Russian Federation

This research work revealed the advantages of a score-rating system (BRS) in a higher educational institution and proved that BRS can be applied in the educational process as a knowledge assessment system and one of the means to increase academic motivation, develop independent activity skills, develop initiative, leadership qualities of students.

Keywords: point-rating system, knowledge assessment system, intermediate certification. 
В настоящее время существует множество балльно-рейтинговых систем, которые используются для определения уровня знаний обучающихся. Каждая из них построена на различных критериях оценивания, которые зависят от многих факторов. Благодаря БРС появляется возможность обнаружить студентов-лидеров с отличным и хорошим уровнями успешности, на основе которых складывается общая картина деятельности группы и кафедры. Это помогает определить вектор дальнейших усилий по подготовке студентов [1]. Также БРС позволяют проследить динамику результатов учёбы студентов и сравнить их. С данной целью был проведён анализ успеваемости студенческих групп и были сделаны следующие выводы:

- БРС исключает возможность организации групповой работы, т.к. рейтинг индивидуален и каждый работает исключительно на свой результат, что в свою очередь может привести к некоторой разобщённости студентов в группе и исключению формирования навыка работы в команде [2].

- БРС требует больших затрат времени даже в рамках одного раздела одной дисциплины. И если преподаватель работает на нескольких кафедрах сразу или ведёт несколько дисциплин, или преподаёт на разных курсах, то его временные затраты увеличиваются в несколько раз. Если добавить к этому то время, которое необходимо на деление заданий по уровню сложности, то появляется вероятность того, что БРС автоматически исключает любые другие виды деятельности, кроме преподавания.

- Студенты, пропускающие занятия даже по уважительным причинам (больничный или свободное посещение) автоматически теряют определенное количество баллов за посещение занятий. В результате этого рейтинг падает, несмотря на уважительные причины.

- Если в группе большинство студентов амбициозны, отличаются высоким уровнем самоорганизации, мотивированы на учёбу и учатся преимущественно на 4 и 5, то получе- 
ние хороших результатов ожидаемо. Но если допустить, что данная система будет использована в группах с более низким уровнем амбиций, самоорганизации и учебной мотивации, то есть вероятность того, что данная система не будет располагать достаточным инструментарием для повышения мотивации к учёбе и посещению. Соответственно, большинство таких студентов осознает необходимость повышения рейтинга ближе к зачётной неделе, а не во время семестра. Следовательно, количество должников, а также тех, кто не успел, не смог или не захотел набрать нужное количество баллов, возрастёт в разы по сравнению с традиционной системой оценки. А это может явиться дополнительным стрессом как для студентов, так и для педагогов. Однако, несмотря на данные нюансы, большинство студентов в целом положительно отнеслись к данной системе оценки. Хотелось бы отдельно прокомментировать то, что студентов привлекает возможность самим прогнозировать свой успех и выбирать виды и формы контроля, видеть пробелы в знаниях и восполнять их.

Проанализировав результаты, мы пришли к выводу, что данная система оценки определяет конечный результат, заставляет студентов упорно трудиться. Эта система оценки заинтересовала студентов своей необычностью, новизной, расширила диапазон времени сдачи пройденного материала, повысила самостоятельность студентов [3].

Таким образом, к основным преимуществам БРС можно отнести:

- повышение мотивации студентов к освоению образовательных программ;

- повышение уровня организации образовательного процесса в вузе;

- повышение объективности и достоверности оценки уровня подготовки специалистов [4];

- снижение роли случайных и субъективных факторов при оценивании образовательных компетенций студентов;

- стимулирование состязательности в учебе; 
- стимулирование студентов к участию в научно-исследовательской деятельности;

- создание объективных критериев для определения кандидатов на продолжение обучения (магистратура, аспирантура).

Таким образом, БРС предполагает текущий контроль за успехами в учёбе, является количественной оценкой качества освоения образовательной программы. БРС позволяет создать максимально комфортную среду обучения и воспитания, позволяет перевести учебную деятельность из необходимости во внутреннюю потребность.

\section{Список литературы}

1. Зарипова Р.С. Особенности и тенденции развития современного инженерного образования / Р.С. Зарипова, О.А. Пырнова / Современные исследования социальных проблем. Красноярск: НаучноИнновационный Центр, 2018. Т.9. №8-2. С. 43-46.

2. Зарипова Р.С. Роль когнитивных технологий в современном образовании / Р.С. Зарипова, А.А. Шакиров / Информационные технологии в строительных, социальных и экономических системах. 2018. № 1-2 (11-12). С. 63-65.

3. Ромашкин В.А. Информационные технологии и их внедрение в процесс обучения / В.А. Ромашкин, А.А. Шакиров, Р.С. Зарипова / «Цифровая культура открытых городов»: Сборник материалов Международной научно-практической конференции. Екатеринбург. 2018. С. 440-443.

4. Зарипова Р.С. Исследование влияния информационных технологий на формирование ценностных ориентаций современных студентов / Р.С. Зарипова, Н.Г. Бикеева / Современные исследования социальных проблем. 2018. Т. 9. № 7-2. С. 110-113.

\section{References}

1. Zaripova R.S. Osobennosti i tendencii razvitiya sovremennogo inzhenernogo obrazovaniya / R.S. Zaripova, O.A. Pyrnova / Sovremennye issle- 
dovaniya social'nyh problem. Krasnoyarsk: Nauchno-Innovacionnyj Centr, 2018. T.9. №8-2. S. 43-46.

2. Zaripova R.S. Rol' kognitivnyh tekhnologij v sovremennom obrazovanii / R.S. Zaripova, A.A. SHakirov / Informacionnye tekhnologii v stroitel’nyh, social'nyh i ekonomicheskih sistemah. 2018. № 1-2 (11-12). S. 63-65.

3. Romashkin V.A. Informacionnye tekhnologii $i$ ih vnedrenie $v$ process obucheniya / V.A. Romashkin, A.A. SHakirov, R.S. Zaripova / «Cifrovaya kul'tura otkrytyh gorodov»: Sbornik materialov Mezhdunarodnoj nauchno-prakticheskoj konferencii. Ekaterinburg. 2018. S. 440-443.

4. Zaripova R.S. Issledovanie vliyaniya informacionnyh tekhnologij na formirovanie cennostnyh orientacij sovremennyh studentov / R.S. Zaripova, N.G. Bikeeva / Sovremennye issledovaniya social'nyh problem. 2018. T. 9. № 7-2. S. 110-113. 